\title{
English Christmas Pantomime: Theatre or Community Activism
}

\author{
Pete Reader, MFA \\ Seton Hall University, South Orange, NJ, USA
}

\begin{abstract}
How is English Christmas panto community activism? The structure of pantomime has not changed in a hundred years, but allows for local creativity to work within its framework to be both family entertainment and social satire. This basic structure is founded on a children's story like Puss'n'boots or Cinderella. The story and character types remain the same; but the community can add their own jokes and commentary to make the play relevant to themselves and their community. What is added by the community says a lot about who they are and what they care about. The company Price-Waterhouse-Coopers produces their pantomime as management training and team building while engaging the community. The Basel Swiss panto raises money for African Charities. The Maplewood, NJ panto raises money for the homeless and the Jaguar Charity panto in Birmingham performs to disadvantaged children and adults. The productions can be extravagant or threadbare, but share the same goal of raising cheer and goodwill to the benefit of the community. What is it, then, about panto that brings a community together in such civic mindedness?
\end{abstract}

Keywords: English Christmas pantomine, community engagement, theatre, activism

\section{Historical Overview}

English Christmas Pantomime is an odd form of theatre that serves as a vehicle for local communities to come together, in a form of civic activism, to present plays for the benefit of the community and local charities. Every year local producers write or license pantomime plays and organize their performances with members of the community. Some productions are large and gaudy, while others are small depending on the resources of the community. What they present can say a lot about a community and what they care about. What is it, then, about English Christmas Pantomime that lends itself to such community engagement and activism?

English Christmas Pantomime began in London in the early 18th century as a form of Italian Commedia Dell' Arte, which was popular at the time. John Rich, the manager of the Drury Lane Theatre, adapted Commedia to suit himself and his audiences. He wrote and starred in his productions playing Harlequin, in what was called a Harlequinade. No dialogue was written. It was a series of scenes that showcased spectacular stage effects, and John Rich's performance. Performing as Harlequin, Rich would slap scenery with his magic stick to instigate a transformation of the setting into another more fantastic setting. This stage effect would later be called the transformation scene.

The basic premise for English Pantomime, even at its start was farce. Harlequin and Columbine were always in love and Pantalone was always trying to keep them apart. This conflict turned into a long chase motivating the

Pete Reader, MFA, Associate Professor, Theatre, Seton Hall University. 
scenic transformation, which was an audience favorite. While the Harlequinade faded in popularity, the basic characters and transformation scenes remained in another guise. Audiences in theatre change regularly reflecting the change in demographics of their communities. For theatres and their productions to survive, they need to adapt. With the rise of the middle class in the 19th century, due in part to industrialization, English Christmas Pantomime was modified to appeal to the values and tastes of the new middle class who comprised a growing audience.

To understand the changes and evolution of Pantomime to what it is today, it needs to be seen through a social and cultural perspective. Wendi Griswold, author of Renaissance Revivals, postulates:

To understand a particular cultural object within society, and the form the object takes, we need to take into account not only the cultural attributes, but also the intentions of the producer and its audience's reception, as well as the social context. (1986, p. 4)

A fair example of this paradigm are the changes wrought by Pantomime performer Joey Grimaldi who performed from 1790-1823. Grimaldi was a great physical comedian in his role of Clown in the Harlequinade. He became so outstanding in his performance, to the appreciation of audiences, that producers wrote material just to showcase his performance. No longer a secondary character, Grimaldi wore loud, bright costumes and played sly tricksters that got the better of unjust characters. His colorful costumes and stage routines transcended the pantomime's story to become stage convention and expected by the audience in every performance. Probably his best known gag was his stealing of sausage links. It was not simple theft, but an act of childish defiance against an unjust merchant. In a performance, Clown, or a similar foolish character, steals a string of sausages which are dragged trailing across the stage, sometimes chased by a trained dog, to the cheers of the audience. Inheritors of Grimaldi's role onstage did their best to emulate his gag. It has remained a staple of Panto comedy. English Pantomime is shaped by popular stage business handed down from previous performances. Audiences grew to expect it, which has structured pantomime's conventions to what they are today.

Another innovation helped by Joey Grimaldi was the slow move away from Commedia and the Harlequinade. Grimaldi appeared in the panto Robinson Crusoe as Friday, the manservant, in the late 1790s. It was one of the first adaptations of a popular literary work into a pantomime farce. He later followed this performance with Harlequin Mother Goose in 1806. The stories of Mother Goose were first published in English in 1729. These stories included Little Red Riding Hood, Puss'n'boots, and Sleeping Beauty. The brothers Grimm published their first collection of stories in 1812, which included Babes in the Wood and Cinderella as well. With improved printing technology and an improved educational system, children's books became popular and popular stories became well known. Producers were quick to pander to audience tastes and interests. All these popular children's stories are now the foundation to many Christmas pantomime plots, populated by long standing comic conventions.

English Christmas Pantomime is a gift of sorts for the holiday season. Producers have encouraged families to come to the Theatre to see a familiar story and share a laugh. English Christmas Pantomime has been presented in London for almost three hundred years. These performances have oriented the audience and their expectations into a holiday tradition. Families share the experience of the performance and come back generation after generation, building on their previous experience and passing along their expectations to the next generation. An 
audience who may look forward to Hamlet's poetic soliloquies in traditional theatre will look equally forward to the running of the sausages across the stage in English Christmas Pantomime.

Audience expectations define much of the cast and stage business of English Christmas Pantomime. As a result it has evolved into a strong structure. It does not matter what story frames the plot, the characters and their conflicts remain the same from the days of the Harlequinade to today. The cast lists the principal boy, which is the Harlequin role (played by a woman dressed a young man). The principal girl is the Columbine role (played by an ingenue). The old mother is played by a male comic in drag, known as the Dame role. The comic fool is the Clown role. The villain is played with traditional melodrama. The panto animal (horse, deer, bear, or camel) is funny stage business. The rest of the casting depends on the story vehicle.

At the beginning of a show, following tradition, the principal boy or the comic fool enters from stage right, crosses center and introduces the show. He/she explains the basic conflicts and coaches the audience as to when to call out during certain stage action ("Look behind you" or "Yes, it is; No, it isn't"). The lovers are presented and then the villain from Stage Left. The villain's over-reaching ambitions drive the action as he/she tries to ruin everyone's fun for his/her own pleasure. Sometimes, a fairy godmother (from the early days of the Harlequinade) appears as a Deus ex machina character to right the villain's wrongs. In Ali Baba and Aladdin, it's usually a genie.

After introductions, the story begins. There is a strong moral order in Christmas Pantomime. The villain is the traditional devil who must be thwarted. His/her plans represent an unjust authority that oppresses the other characters. It is up to the principal boy and his/her accomplices who do the thwarting with the audience's help. The conflict between good and bad is easily identifiable. The villain's over-reaching ambitions are outrageous and must be dealt with in a similar way. As shaped by Grimaldi, comedy is just the weapon to defy the efforts of the panto villain's unjust authority. At the end of the play, order and justice are restored. The lovers united. It's a cathartic fairy tale ending for a middle class audience of children and their parents.

Ironically, Panto's conflicts often parallel and parody politics in contemporary society. William Makepeace Thackery, in his writings, compares the vile court politics of King George III to the absurdity of pantomime characters bumbling through a plot. He describes King George III as a maniacal pantomime villain who forces the sweet Princess Caroline of Brunswick to marry his ne'er-do-well son, George IV. Princess Caroline's fate lacked a happy pantomime ending.

\section{Panto Structure}

English Christmas Pantomime provides a safe context for farce and satire in a topys-turvy fantasy world. Of course, there's the usual battle between good and evil, but panto evil is silly, its good virtuous, and its conflicts resolved happily ever after. English Pantomime borrows old fairy tales and dresses them up with slapstick, puns, and jokes. Its humor is meant to diffuse sharp criticism of an established order, which, in the case of Panto, would be the aspirations of the Panto villain; but could easily be construed as a metaphor for society. Society isn't perfect. We all wish it could be, and as easily solved with the wave of a fairy wand or a genie's command. Since it's never that simple, English Christmas Pantomime is a comic salve for society's frustrations of what cannot be fixed.

Physical comedy is timeless, but an old joke can be stale. English Christmas Pantomime's humor lies in its jokes and puns to remain popular. To engage its audiences, it must have contemporary and topical references that 
relate to them beyond the fairy tale story. Writers of Pantos probably work harder on dialogue, double entendres, puns, and punchlines than any other aspect of the plot. It is here that Panto excels at taunting authority and teasing social conventions. It's humor that is meant to bring the audience together in a shared laugh. Everyone is in on the joke and the humor is localized to the community. Laughter with community engagement is civil activism. By Laughing, the audience criticizes social conventions and authority without the formal confrontation of a civic meeting. Humor disarms the sharp criticism by being dressed as a clown that makes the audience laugh.

A recent example of poking fun at authority was the 2013 production of the Rutherglen Town Hall players' Jack and the Beanstalk. ${ }^{1}$ Following the traditional story, Jack must sell the family cow. The cow's name is Thatcher, after the former prime minister of Great Britain, Margaret Thatcher. Jack explains to the audience that the reason the cow is named Thatcher is because she's a cow that won't produce milk for the children. It is a clear reference to the prime minister's austerity reforms that rocked Great Britain in the 1980's. Sadly, the producers changed the name of the cow, fearing the joke to be too offensive.

What makes English Christmas Pantomime enduring is its flexibility to add or take away stage business depending on local audience's tastes, but the basic structure remains the same. At its heart, it is a children's show. What makes it unique is what producers choose to add in the nature of comedy (gags and jokes) to the established structure. Producer and audience have a co-dependent relationship. Because the audience has been conditioned in its expectations, a producer needs to be careful not to disappoint the traditional stage business; but add a few topical references in the jokes without being too offensive. What is added says a lot about a community and its values. What is left out signals a change in audience tastes.

In the 19th century, Great Britain’s expansion into China brought an interest in all things Asian. The story of Aladdin, which was set in China and Bagdad, quickly adapted to pantomime to cash in on the Asian fad. An 1813 production of Aladdin starred Joey Grimaldi as a comic slave along with the addition of a comic Chinese laundress. By mid-century, the laundress evolved into Widow Twankey, a pantomime dame, who runs a laundry with her sons, Wishy \& Washy. At the time, 19th century Chinese immigrants, without much financial means, found that laundries were an easy business for them to establish, which could be run by the whole family. Their businesses were often run from their homes in the poorer section of cities. The confusing appearance of their business became comic stage fodder, particularly with a comic chase through hanging laundry. These Aladdin productions were quite successful, but the 19th century characters were firmly based in Asian stereotypes for comic effect. Most versions today still find Aladdin working in Widow Twankey's Chinese laundry with her sons. Their characters, though, have become more contemporary comic stereo-types than Chinese.

TLC Creative is a contemporary writers collective that write pantomimes for performance and licensing. They claim on their website (www.tlc-creative.co.uk) that their plays offer:

"Clean fun and no smut!

Plenty of jokes - old and new!

Slapstick, visual gags and lots of movement!

Slosh / mess / goo scenes!

It's behind you scenes!

${ }^{1}$ See Douglas Dickie, “Panto Cow at Rutherglen”, 12/18/2013. 
Lots of audience participation

Clearly defined goodies and baddies!

Loud and colourful characters"

The TLC Creative authors follow the Panto structure adding their own material along the way. In their script for 1001 Arabian Nights and a Matinee, the principal girl is named Jasmina. She must marry before she's twenty-one or the evil Vizier will take over the city of Baghdad. The former thief, and principal boy, Ali Barber (not Aladdin), comes to her aid. The character names carefully tread around the successful Disney property Aladdin, which brings in pop culture references for the audience. An old story has an odd contemporary feel of a Disney musical, which shouldn’t be surprising. Disney’s musical Aladdin is basically a Pantomime that was pumped up to a Broadway musical. Disney, for their part, kept the story Middle Eastern, rather than follow the traditional Asian storyline.

\section{Community Engagement}

In a 2014 PEMADS production of Snow White in Port Elizabeth, South Africa, Prince Charming used his cell phone with the app Trip Advisor to find a local hotel. A passing character recommends that he tries the local Y, which leads to a chorus of the song YMCA. Later, the evil queen looks in her magic mirror and comments that she is often mistaken for the singer Madonna. Another overweight character claims to be a "Secret Victoria model” in another life. Topical references are important to a show's humor and a touchstone to contemporary life.

Hilarly Mackelden is the author of The Blue Ridge Cinders. The author sets the Cinderella story in the Blue Ridge Mountains of Virginia. The cast includes FBI agents 1 \& 2, a town drunk, and Sheriff Lisa (in the Dame role). In Maplewood, New Jersey, the producers Suburban Legend produced The Last Chance Saloon in January, 2016. These pantos show the adaptability of the format to suit most any kind of local community.

A great part of English Christmas Pantomime is its presentation in and around Boxing Day. It is not exactly a religious holiday, but more a civil holiday where gifts traditionally are exchanged and charity given. London Theatre has a long tradition of charity performances dating back to the Elizabethan period, including Shakespeare's Lord Chamberlain's men. It is therefore not surprising that some Panto producers donate a share of their proceeds to local charities and invite disadvantaged youth to matinee performances.

Price Waterhouse Cooper ${ }^{2}$ is a multinational services network of professionals and one of the largest auditing firms in the world. They are not in the business of Theatre per se. They produce pantomime as part of their corporate mission. Every year in London, for almost thirty years, PwC managers are given the responsibility of producing a pantomime. Over 200 employees participate in all aspects of production, including performance. According to the PwC website, ${ }^{3}$ the company views this activity as a form of management training in leadership, team building, planning, and time management while engaging the community and promoting corporate good will. Their last production was Dick Whittingham and His Cat for the 2015 season. The previous season was Cinderella, where they gave away 7000 tickets to disadvantaged children through their schools and inner city charities. PwC also provided transportation and goodie bags. Imagine seven thousand children indoctrinated into the world of English Christmas Pantomime and thereby, creating a future audience and an appreciation for PwC's generosity.

\footnotetext{
2 See from http://www.pwc.co.uk/pantomime.

${ }^{3}$ See from http://www.pwc.co.uk/pantomime.
} 
Price Waterhouse Cooper is not the only corporation to participate this way. There is also the British Airways Cabin Crew Entertainment Society. ${ }^{4}$ They are volunteer crew members who have produced an annual pantomime for charities for over forty years and raised over a million pounds. The 2014 beneficiaries of their work include Christopher's Smile (Children's Cancer), Combat Stress (helping combat vets), Guide Dogs, Beacon House (Christian Health charity), and Colchester Deaf Club. They also perform free mid-week matinees for disadvantaged youth and the elderly, much like PwC. BACCES uses pantomime to engage and build positive relationships with the community. The BACCES committee members choose to donate to different charities every year.

Small communities engage in the same kind of performance charity on a much smaller scale. The producer DeadGood, gave a 2014 production of Wotcha Gotcha Maplewood, New Jersey, in which their net profits of \$6000 were divided between the New Jersey Foodbank and Rent Party, a charity that helps poor families afford housing. ${ }^{5}$ Maplewood's Suburban Legend's 2015 pantomime Robin Hood, raised \$2000 for Rent party and St. Huberts Animal Welfare center. Charities don't always have to be local. The Basel English Pantomime Club ${ }^{6}$ in Basel, Switzerland, donates to the Starehe Girls Center, a school for under-privilege girls in Kenya, Africa. The chosen charities are often where the producers' or audience interests lie.

The Wellington Improvisational Troupe ${ }^{7}$ in New Zealand sees their mission as engaging the community in humor through improvisation. Their charity is that of sharing skills with the community. Their philosophy, stated on their web page, is that through participation their work will "Alleviate the fear of being stared at", "Turn dull people into brilliant people”, "Improve interpersonal skills”, "Develop story-telling skills”, “And give back to the stage”. WIT works with its ensemble to create trust and to take risks that engage each other as well as the audience in order to make a connection that both share. Most often that connection is through a silly farce of a Christmas pantomime. Broad characters and silly costumes free the inhibited to participate in a group activity where they are directed to let go and have fun. The audience is encouraged to participate in the performance, which panto easily lends itself.

In Turkey, Christmas Pantomime is used as language training. Speech Bubbles, a youth troupe at the International Training Institute in Istanbul uses English Christmas Pantomime to teach English through performance. Their goals are twofold: Education and charity. ${ }^{8}$ They educate their students by performance of a panto play in English and their show proceeds go to charity. All participants are volunteers who donate their time, expertise, and services to produce something fun for the positive benefit of children and charities that support under-privileged youth. The students learn English and the gift of giving back through their own efforts. This is social activism. Its actions improve their community.

\section{Conclusion}

English Christmas Pantomime will continue to evolve as long as audiences enjoy it. The participatory nature of its performance provides a safe vehicle to laugh at evil and to cheer the good in a co-conspiracy between

\footnotetext{
${ }^{4}$ See from http://www.bacces.com.

5 See from http:// www.villagegreennj.com/arts/bristish-panto-theatre.returns.

${ }^{6}$ See from http://www.baselpanto.org.

7 See from http:/www.wit.org.nz.

${ }^{8}$ See from http:/www.speechbubbles.org.
} 
performer and audience. Local Pantomime groups recruit their cast and crew from the community and thereby, ensure an impartial audience of friends and relatives who come out to support them. The success of a show empowers the community and draws them closer together. Their success is not measured in financial gain. It is measured by community engagement and their donations to local charities. Aiding charities is community activism. It favors under-privileged children, more often than not, in their own communities. The experience is empowering and positive for everyone involved. Audience and performers share the success. Staging a show for charity is a very old trope that has always won the hearts of an audience. What could be a better way to improve society than with entertainment in the guise of a good old fashion English Christmas Pantomime?

We've gotta have a great show, with a million laughs ... and color ... and a lot of lights to make it sparkle! And songs—-wonderful songs! And after we get the people in that hall, we've gotta start em in laughing right away! Oh, can't you just see it...? (Berkley, 1938)

\section{References}

"BACCES Welcome”. (2015, May 13). British airways cabin crew entertainment society. Retrieved 2015, June 20 from http://www.bacces.com/

Berkley, B. (Director). (1938). Babes in arms [Film]. Hollywood, CA: MGM.

Dickie, D. (2013, December 18). Panto cow at Rutherglen Town Hall has to change its name. Daily Record \& Sunday Mail. Retrieved 2015, June 10 from http://www.dailyrecord.co.uk/news/local-news/panto-cow-rutherglen-change-its-2938943

English Pantomime Group. (n.d.). Charities. Retrieved 2015, June 25 from http://www.baselpanto.org/club/charities/

Griswold, W. (1986). Renaissance rivals city comedy \& revenge tragedy in London theatres, 1576-1980 (1st ed.). Chicago \& London, Illinois: University of Chicago Press.

Johnstone, K. (1999). WIT creative philosophy. Wellington Improvisational Troupe. Retrieved 2015, June 20 from http://wit.org.nz/?page_id=116

MacKelden, H. (n.d.). Blue ridge cinders. Lazy bee scripts. Retrieved 2015, June 2 from http://www.lazybeescripts.co.uk/scripts/script.aspx?iSS=1781

PEMADS. (2014). Little Theatre, Port Elizabeth South Africa. Retrieved from https://www.youtube.com/results?Search_query=Pemads+Snow+White

PwC Pantomime. (2015). About the Pantomime. Retrieved 2015, June 12 from http://www.pwc.co.uk/pantomime/about.jhtml

Taylor, G. (1993). Players \& performers in the Victorian theatre (1st ed.) Manchester: Manchester University Press.

Thackery, W. (1904). Four Georges. In The complete works of William Makepeace Thackery. London: Harper.

TLC Creative. (n.d.). Pantomimes. Retrieved 2015, June 12 from http://www.tlc-creative.co.uk/pantomimes.htm

Wilson, A. E. (1934). Christmas pantomime; the story of an English institution (1st ed.). London: G. Allen and Unwin.

Yagid, J. (2014, December 28). British panto theatre returns. The village green. Retrieved 2015, July 8 from http://villagegreennj.com/arts/british-panto-theater-returns-burgdorff/ 